\title{
Zirconium-Mediated Synthesis of Multi-substituted Dibenzosilole and Benzonaphthosilole Derivatives
}

\author{
Hongmei Qu ${ }^{1} \cdot$ Xin Zhang $^{1} \cdot$ Xu Chen ${ }^{2} \cdot$ Hui Zhang ${ }^{1} \cdot$ Yican Men $^{1} \cdot$ Junqiu Li ${ }^{1}$
}

Received: 8 March 2018 / Revised: 7 April 2018 / Accepted: 13 April 2018 / Published online: 16 May 2018

(c) The Author(s) 2018

\begin{abstract}
In this study, a new zirconium-mediated cycloaddition for preparing dibenzosilole derivatives was developed using siliconbridged diynes and electron-withdrawing alkynes as starting materials. The preparation of silicon-bridged diynes from 1-bromide-2-iodobenzene, terminal alkynes, and dimethyldichlorosilane was also studied. Unlike in the previous synthesis methods, much higher yields of electron-withdrawing group-substituted dibenzosilole derivatives were obtained. In addition, a new synthesis strategy for preparing benzonaphthosilole derivatives using internal alkynes, 1,4-dibromobenzene, and electron-withdrawing alkynes as starting materials is proposed. Compared with previous methods, alkyl, phenyl, and electron-withdrawing groups can be successfully introduced onto aromatic rings, and the positions of these substituents can be easily controlled. The cycloaddition reactions for dibenzosilole and benzonaphthosilole derivatives are highly efficient one-pot processes, and the raw materials are available and easily prepared. Using these new methods, a series of novel multisubstituted dibenzonsilole and benzonaphthosilole derivatives were obtained effectively.
\end{abstract}

Keywords Zirconium-mediated reactions $\cdot$ Dibenzosilole derivatives $\cdot$ Benzonaphthosilole derivatives $\cdot$ Multi-substitution

\section{Introduction}

Silole derivatives have attracted considerable attention in recent years because of their $\sigma^{*}-\pi^{*}$ conjugation and aggregation-induced emission (AIE) [1] properties. The $\sigma^{*}-\pi^{*}$ conjugation decreases the lowest unoccupied molecular orbital energy level, endowing silole with good electron acceptance ability [2]. As AIE molecules, silole derivatives are promising candidates for electron-transporting and lightemitting layers in optoelectronic devices [3, 4].

Dibenzosilole molecules have received much attention because of their applications as important building blocks of different donor units and new conjugated polymers for solar cells [5-7], electroluminescence materials [8], and explosives detection [9]. Many researchers have adopted the ringclosure method [10-15] for preparing dibenzosilole derivatives. However, this method has some limitations such as the

Hongmei Qu

ququhongmei@126.com

1 Key Laboratory of Systems Bioengineering (Ministry of Education), School of Chemical Engineering and Technology, Tianjin University, Tianjin 300350, China

2 Tianjin Kingsrial S\&T Co., Ltd, Tianjin 300384, China difficulties in introducing substituents onto benzene rings and preparing raw materials. Matsuda et al. [16] reported an iridium(I)-catalyzed cycloaddition method for synthesizing dibenzosilole derivatives (Scheme 1), in which electrondonating groups were introduced onto benzene rings. Unfortunately, the reaction was sluggish when $\mathrm{R}^{3}$ was a dimethoxycarbonyl group (an electron-withdrawing group, EWG), and the product could hardly be obtained (yield $=7 \%$ ). Interestingly, we found that silicon-bridged diynes can react with $\mathrm{Cp}_{2} \mathrm{ZrBu}_{2}$ and then undergo a cycloaddition reaction to yield $79 \%$ of dimethoxycarbonyl-substituted dibenzosilole derivative. In addition, various silicon-bridged diynes were subjected to a zirconium-mediated cycloaddition reaction to yield 64-79\% of novel alkoxycarbonyl-substituted dibenzosilole derivatives (Scheme 1).

The synthesis of benzonaphthosilole (benzo[b]silafluorene) derivatives has seldom been reported although they are promising silole derivatives with extended $\pi$-conjugation based on dibenzosilole (Fig. 1) [17-19], and no synthesis of benzonaphthosilole derivatives has been reported where alkyl, phenyl, and EWGs groups were substituted on the aromatic rings. Because substituents can effectively regulate molecular properties, lack of a synthesis method has limited the performance 
Scheme 1 Iridium(I)-catalyzed cycloaddition and zirconiummediated cycloaddition synthesis of dibenzosilole derivatives

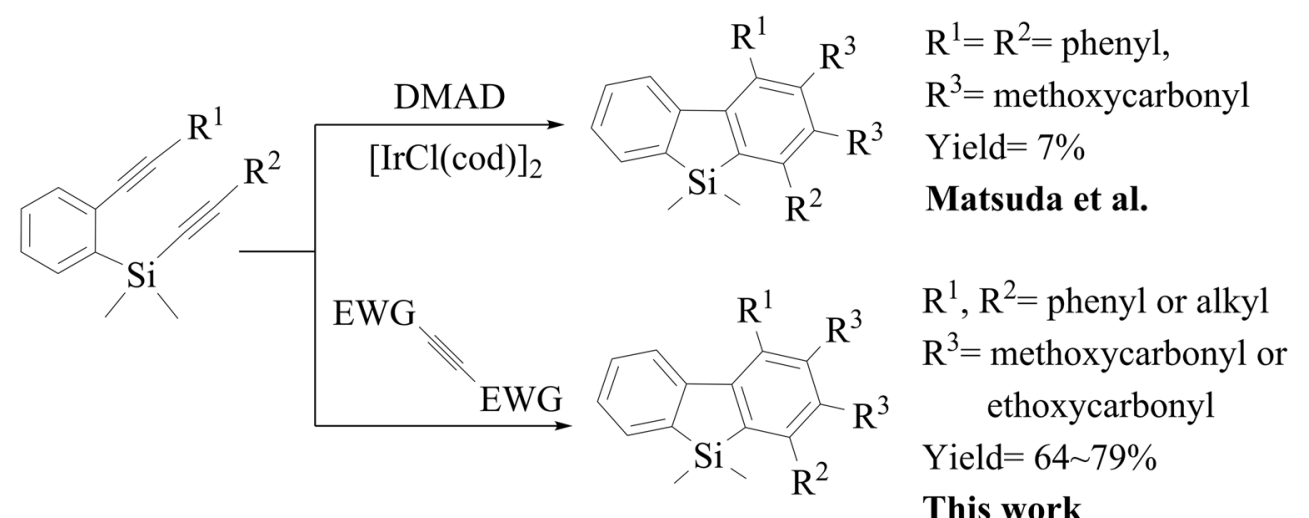

This work
Fig. 1 Rhodium-catalyzed reaction (previous studies) and zirconium-mediated cycloaddition (present study) of benzonaphthosilole derivatives synthesis
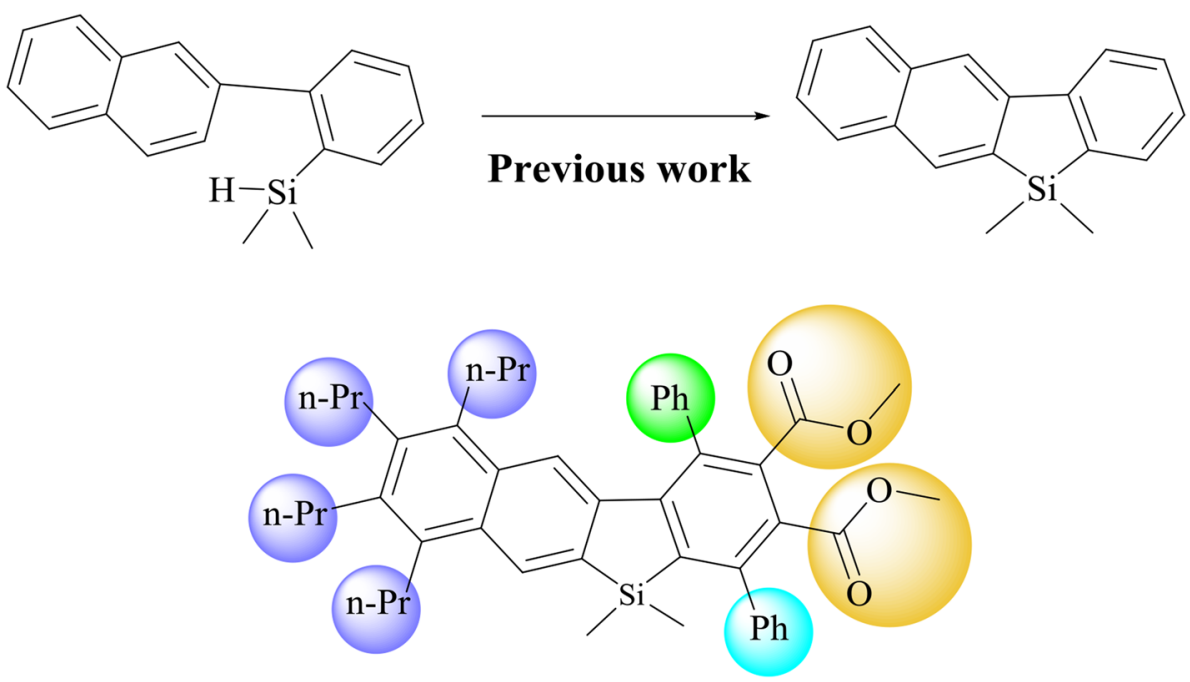

This work

studies of benzonaphthosilole derivatives. Fortunately, a multi-substituted benzonaphthosilole derivative (Fig. 1) is obtained by our strategy, which combines zirconiummediated coupling, Sonogashira coupling, and the novel zirconium-mediated cycloaddition in moderate yield. Using this strategy, propyl, phenyl, and dimethoxycarbonyl groups can be efficiently and selectively introduced onto aromatic rings.

In our previous studies, zirconacyclopentadienes have been used as intermediates for the synthesis of naphthacene derivatives, multi-substituted benzenes, and 1,2,3,4-tetraalkyl-1,4-diarylbutadienes [20-22]. In these studies, zirconacyclopentadienes were formed using silicon-free terminal alkynes and internal alkynes as starting materials. However, in this study, silicon-containing acetylenes, i.e., silicon-bridged diynes, were used as the starting materials for zirconium-mediated cycloaddition. A series of dibenzosilole and benzonaphthosilole derivatives were efficiently synthesized from silicon-bridged diynes by one-pot processes. The zirconium-mediated cycloaddition showed good group tolerance for silicon-bridged diynes having different alkyl and aryl groups.

\section{Experimental Details}

\section{Reagents and Measurements}

Anhydrous tetrahydrofuran (THF) was distilled from sodium and benzophenone under dry nitrogen. Catalysts $\mathrm{PdCl}_{2}\left(\mathrm{PPh}_{3}\right)_{2}$ and $\mathrm{Pd}\left(\mathrm{PPh}_{3}\right)_{4}$ were purchased from Woerjiming, China, and n-butyllithium (n-BuLi) was purchased from Ouhechem, China. All other chemicals and reagents were purchased from TCI (Japan) and Aladdin (China) and were used without further purification.

All reactions were carried out under nitrogen protection except for special instructions. ${ }^{1} \mathrm{H}$ and ${ }^{13} \mathrm{C}$ NMR spectra were recorded on a Bruker AVANCE III spectrometer (Switzerland) in deuterated chloroform using tetramethylsilane as the internal standard. Mass spectra were obtained on an LCQ 
Deca XP MAX (Thermo Fisher, USA) mass spectrometer system. Thin-layer chromatography (TLC) was performed using Energy GF254 plates.

\section{Synthesis of Alkoxycarbonyl-Substituted Dibenzosilole Derivatives}

The preparation of alkoxycarbonyl-substituted dibenzosilole derivatives is shown in Scheme 2. Phenyl, pentyl, and alkoxycarbonyl-substituted dibenzosilole derivatives were synthesized from terminal alkynes and 1-bromo-2-iodobenzene.

\section{General Preparation Procedure of 2-Alkynylbromobenzene} (2)

First, $316 \mathrm{mg}$ ( $0.45 \mathrm{mmol})$ of bis(triphenylphosphine)palladium dichloride $\left(\mathrm{PdCl}_{2}\left(\mathrm{PPh}_{3}\right)_{2}\right)$ and $95 \mathrm{mg}(0.5 \mathrm{mmol})$ of cuprous iodide $(\mathrm{CuI})$ were added to $100 \mathrm{~mL}$ of triethylamine, and the mixture was stirred. Then, $4.24 \mathrm{~g}(1.9 \mathrm{~mL}, 15 \mathrm{mmol})$ of 1-bromo-2-iodobenzene and $15 \mathrm{mmol}$ of alkynes (1) were added, and the mixture was further stirred overnight at room temperature. The mixture was filtered, and the filtrate was evaporated under a reduced pressure. The residue was purified by flash column chromatography on silica gel with n-hexane as eluent to obtain 2-alkynylbromobenzene.

\section{Spectroscopic data}

1-bromo-2-(phenylethynyl)benzene (2a) [23]: ${ }^{1} \mathrm{H}$ NMR $\left(400 \mathrm{MHz}, \mathrm{CDCl}_{3}\right): \delta 7.65-7.56(\mathrm{~m}, 4 \mathrm{H}), 7.38(\mathrm{dd}, J=4.9$, $1.9 \mathrm{~Hz}, 3 \mathrm{H}), 7.31(\mathrm{td}, J=7.6,1.2 \mathrm{~Hz}, 1 \mathrm{H}), 7.19(\mathrm{td}, J=7.8$, $1.7 \mathrm{~Hz}, 1 \mathrm{H})$

1-bromo-2-(pentylethynyl)benzene (2b) [24]: ${ }^{1} \mathrm{H}$ NMR $\left(400 \mathrm{MHz}, \mathrm{CDCl}_{3}\right): \delta 7.54(\mathrm{dd}, J=8.0,1.3 \mathrm{~Hz}, 1 \mathrm{H}), 7.41$ (dt, $J=7.7,1.3 \mathrm{~Hz}, 1 \mathrm{H}), 7.21(\mathrm{td}, J=7.6,1.2 \mathrm{~Hz}, 1 \mathrm{H}), 7.10$ (td, $J=7.7,1.4 \mathrm{~Hz}, 1 \mathrm{H}), 2.45(\mathrm{t}, J=7.0 \mathrm{~Hz}, 2 \mathrm{H}), 1.64$ (p, $J=7.1 \mathrm{~Hz}, 2 \mathrm{H}), 1.52-1.43(\mathrm{~m}, 2 \mathrm{H}), 1.36(\mathrm{~h}, J=7.2 \mathrm{~Hz}, 2 \mathrm{H})$, $0.95-0.89(\mathrm{~m}, 3 \mathrm{H})$
General Preparation Procedure for Silicon-Bridged Diynes (5)

First, $6.96 \mathrm{~mL}(2.5 \mathrm{~mol} / \mathrm{L}, 17.4 \mathrm{mmol})$ of $\mathrm{n}-\mathrm{BuLi}$ was added dropwise to a solution of $2(15 \mathrm{mmol})$ in $35 \mathrm{~mL}$ of THF at $-78{ }^{\circ} \mathrm{C}$, and the mixture was stirred for $1 \mathrm{~h}$. Then, $7.1 \mathrm{~mL}$ of dimethyldichlorosilane $\left(\mathrm{Me}_{2} \mathrm{SiCl}_{2}\right)$ in $3 \mathrm{~mL}$ of THF (cooled to $-78^{\circ} \mathrm{C}$ first) was added to the mixture in one portion, and the obtained mixture was gradually warmed to room temperature. After stirring for $18 \mathrm{~h}$, the reaction was quenched with $\mathrm{n}$-hexane, the mixture was filtrated, and the filtrate was evaporated under a reduced pressure to give crude 1-chlorodimethylsily-2-alkynylbenzene (3), which was then dissolved in $3 \mathrm{~mL}$ of THF and protected under nitrogen. The solution of $\mathbf{3}$ was used directly in the next step without further purification. The quenching, filtration, and concentration processes of $\mathbf{3}$ were under nitrogen protection.

In a dropwise manner, $8.64 \mathrm{~mL}(2.5 \mathrm{~mol} / \mathrm{L}, 21.6 \mathrm{mmol})$ of $\mathrm{n}$-BuLi was added to a solution of $18 \mathrm{mmol}$ of alkynes (4) in THF $(16 \mathrm{~mL})$ at $-78{ }^{\circ} \mathrm{C}$, and the mixture was stirred at $-78^{\circ} \mathrm{C}$ for $1 \mathrm{~h}$. The solution of $\mathbf{3}$ in THF was added, and the obtained mixture was gradually warmed to room temperature. After stirring for $16 \mathrm{~h}$, the reaction was quenched with water and extracted with ethyl acetate. The solution of organic phase was removed under a reduced pressure, and the residue was purified by flash column chromatography on silica gel with n-hexane and triethylamine $(v / v=100: 1)$ to give silicon-bridged diynes.

Spectroscopic data

1-[(dimethyl)(phenylethynyl)silyl]-2-(phenylethynyl)benzene (5a) [16]: ${ }^{1} \mathrm{H}$ NMR $\left(400 \mathrm{MHz}, \mathrm{CDCl}_{3}\right): \delta 7.82-7.79(\mathrm{~m}$, $1 \mathrm{H}), 7.48$ (ddd, $J=6.4,5.2,2.9 \mathrm{~Hz}, 3 \mathrm{H}), 7.40-7.36(\mathrm{~m}, 2 \mathrm{H})$, 7.33-7.24 (m, 5H), 7.23-7.15 (m, 3H), 0.57 (s, 6H)

1-[(dimethyl)(pentylethynyl)silyl]-2-(phenylethynyl)benzene (5b) [16]: ${ }^{1} \mathrm{H}$ NMR $\left(400 \mathrm{MHz}, \mathrm{CDCl}_{3}\right): \delta 7.87-7.83$ (m, 1H), 7.57-7.53 (m, 3H), 7.39-7.32 (m, 5H), $2.27(\mathrm{t}$, $J=7.2 \mathrm{~Hz}, 2 \mathrm{H}), 1.58-1.49$ (m, 3H), $1.42-1.24$ (m, 5H), 0.88 (t, $J=7.1 \mathrm{~Hz}, 3 \mathrm{H}), 0.56(\mathrm{~s}, 6 \mathrm{H})$

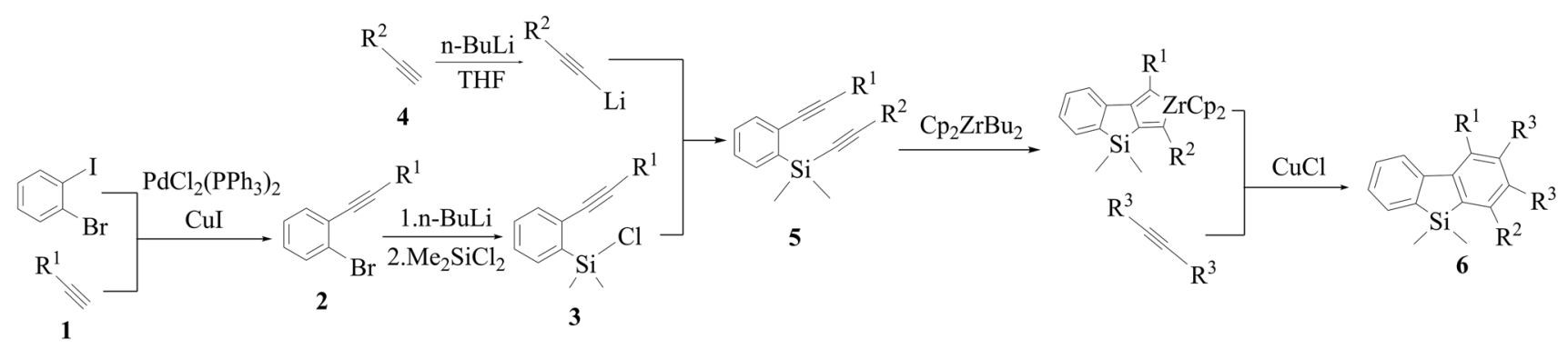

Scheme 2 Synthesis of alkoxycarbonyl-substituted dibenzosilole derivatives 
1-[(dimethyl)(phenylethynyl)silyl]-2-(pentylethynyl)benzene (5c): ${ }^{1} \mathrm{H}$ NMR $\left(400 \mathrm{MHz}, \mathrm{CDCl}_{3}\right): \delta 7.84-7.81(\mathrm{~m}, 1 \mathrm{H})$, 7.47 (ddt, $J=7.7,3.8,1.9 \mathrm{~Hz}, 3 \mathrm{H}), 7.40-7.37$ (m, 1H), 7.28$7.25(\mathrm{~m}, 4 \mathrm{H}), 2.38(\mathrm{t}, J=7.2 \mathrm{~Hz}, 2 \mathrm{H}), 1.58(\mathrm{p}, J=7.3 \mathrm{~Hz}$, $2 \mathrm{H}), 1.41-1.35(\mathrm{~m}, 2 \mathrm{H}), 1.32-1.26(\mathrm{~m}, 2 \mathrm{H}), 0.86(\mathrm{t}$, $J=7.2 \mathrm{~Hz}, 3 \mathrm{H}), 0.56(\mathrm{~s}, 6 \mathrm{H}) .{ }^{13} \mathrm{C} \mathrm{NMR}\left(101 \mathrm{MHz}, \mathrm{CDCl}_{3}\right)$ : $\delta 138.64,135.13,132.35,132.13,129.51,128.70,128.34$, 126.99, 123.33, 107.05, 94.24, 92.72, 81.79, 31.39, 28.35, $22.35,19.70,14.08,-0.60$. LC-MS, $m / z: 331.3[\mathrm{M}+\mathrm{H}]^{+}$

\section{General Preparation Procedure for Dibenzosilole Derivatives (6)}

First, $2.13 \mathrm{~mL}$ of n-BuLi (1.6 mol/L, $3.4 \mathrm{mmol})$ was added dropwise to a mixture of bis(cyclopentadienyl)zirconium dichloride $\left(\mathrm{Cp}_{2} \mathrm{ZrCl}_{2}, 0.5 \mathrm{~g}, 1.7 \mathrm{mmol}\right)$ and $5 \mathrm{~mL}$ of THF at $-78{ }^{\circ} \mathrm{C}$, and the mixture was stirred for $1 \mathrm{~h}$. Then, 5 ( $1 \mathrm{mmol}$ ) was added, and the resulting mixture was heated to $50{ }^{\circ} \mathrm{C}$ for $30-40 \mathrm{~min}$ (5a: $30 \mathrm{~min}, \mathbf{5 b}-\mathbf{c}$ : $40 \mathrm{~min}$ ). The mixture was cooled to $0{ }^{\circ} \mathrm{C}$ and cuprous chloride $(\mathrm{CuCl}, 0.38 \mathrm{~g}$, $3 \mathrm{mmol}$ ) was added, and the resulting mixture was warmed to room temperature for $10 \mathrm{~min}$. Dimethyl acetylenedicarboxylate or diethyl acetylenedicarboxylate (DMAD or DEAD, $4 \mathrm{mmol}$ ) was added and the resulting mixture was heated to $50{ }^{\circ} \mathrm{C}$ for 15-90 $\min$ (6a: $15 \mathrm{~min}, 6 \mathbf{b}$ : $90 \mathrm{~min}, \mathbf{6 c}-\mathbf{d}: 30 \mathrm{~min}$ ). The reaction was quenched with saturated ammonium chloride solution and extracted with ethyl acetate. The solvent of organic phase was removed under a reduced pressure, and the residue was purified by flash column chromatography on silica gel with n-hexane and ethyl acetate $(v / v=5: 1)$ to give 6.

\section{Spectroscopic data}

Dimethyl 9,9-dimethyl-1,4-diphenyl-9-silafluorene-2,3-dicarboxylate (6a) [16]: ${ }^{1} \mathrm{H}$ NMR (400 MHz, $\mathrm{CDCl}_{3}$ ): $\delta 7.53-7.29$ $(\mathrm{m}, 11 \mathrm{H}), 7.14(\mathrm{t}, J=7.2 \mathrm{~Hz}, 1 \mathrm{H}), 6.98-6.92(\mathrm{~m}, 1 \mathrm{H}), 6.48$ $(\mathrm{d}, J=8.2 \mathrm{~Hz}, 1 \mathrm{H}), 3.48$ (s, 3H), 3.45 (s, 3H), 0.06 (s, 6H).

Diethyl 9,9-dimethyl-1,4-diphenyl-9-silafluorene-2,3-dicarboxylate (6b): ${ }^{1} \mathrm{H}$ NMR (400 MHz, $\mathrm{CDCl}_{3}$ ): $\delta 7.56-7.32(\mathrm{~m}$, $11 \mathrm{H}), 7.15$ (t, J=7.2 Hz, 1H), 7.00-6.92 (m, 1H), 6.49 (d, $J=8.1 \mathrm{~Hz}, 1 \mathrm{H}), 4.01-3.90(\mathrm{~m}, 4 \mathrm{H}), 0.96(\mathrm{t}, J=7.1 \mathrm{~Hz}, 3 \mathrm{H})$, $0.89(\mathrm{t}, J=7.1 \mathrm{~Hz}, 3 \mathrm{H}), 0.07(\mathrm{~s}, 6 \mathrm{H}) .{ }^{13} \mathrm{C}$ NMR $(101 \mathrm{MHz}$, $\left.\mathrm{CDCl}_{3}\right): \delta 168.20,167.81,151.95,147.21,146.58,145.79$, $143.33,141.62,141.01,139.04,137.17,135.04,129.58$, $129.46,129.17,128.55,127.88,127.59,127.42,126.58$, $61.20,61.09,13.52,13.37,-2.51$. LC-MS, $m / z: 507.1$ $[\mathrm{M}+\mathrm{H}]^{+}$

Dimethyl 9,9-dimethyl-4-pentyl-1-phenyl-9-silafluorene-2,3-dicarboxylate (6c): ${ }^{1} \mathrm{H} \mathrm{NMR} \mathrm{(400} \mathrm{MHz}, \mathrm{CDCl}_{3}$ ): $\delta 7.59(\mathrm{~d}, J=7.0 \mathrm{~Hz}, 1 \mathrm{H}), 7.47-7.40(\mathrm{~m}, 3 \mathrm{H}), 7.35-7.30$ (m, 2H), 7.17 (t, J=7.15 Hz, 1H), 7.00-6.91 (m, 1H), 6.47 $(\mathrm{d}, J=8.2 \mathrm{~Hz}, 1 \mathrm{H}), 3.88(\mathrm{~s}, 3 \mathrm{H}), 3.44(\mathrm{~s}, 3 \mathrm{H}), 3.03-2.94$ (m, 2H), 1.70-1.60 (m, 2H), 1.52-1.36 (m, 4H), $0.96(\mathrm{t}$, $J=7.1 \mathrm{~Hz}, 3 \mathrm{H}), 0.53(\mathrm{~s}, 6 \mathrm{H}) . \delta 168.52,168.38,147.50$, $146.67,145.86,142.88,140.23,138.95,137.77,133.85$, 131.88, 129.31, 128.26, 127.75, 127.22, 126.13, 51.95, 51.44, 36.05, 32.15, 22.14, 13.72, - 2.84. LC-MS, $m / z$ : $473.2[\mathrm{M}+\mathrm{H}]^{+}$

Dimethyl 9,9-dimethyl-1-pentyl-4-phenyl-9-silafluorene-2,3-dicarboxylate (6d): ${ }^{1} \mathrm{H} \mathrm{NMR}$ (400 $\mathrm{MHz}, \mathrm{CDCl}_{3}$ ): $\delta 8.06(\mathrm{~d}, J=8.2 \mathrm{~Hz}, 1 \mathrm{H}), 7.65(\mathrm{dd}, J=7.1,1.5 \mathrm{~Hz}, 1 \mathrm{H})$, $7.53(\mathrm{td}, J=7.9,1.6 \mathrm{~Hz}, 1 \mathrm{H}), 7.46-7.41(\mathrm{~m}, 3 \mathrm{H}), 7.39-7.35$ $(\mathrm{m}, 1 \mathrm{H}), 7.33-7.29(\mathrm{~m}, 2 \mathrm{H}), 3.97(\mathrm{~s}, 3 \mathrm{H}), 3.53(\mathrm{~s}, 3 \mathrm{H})$, $3.20-3.14(\mathrm{~m}, 2 \mathrm{H}), 1.93-1.83(\mathrm{~m}, 2 \mathrm{H}), 1.62-1.53(\mathrm{~m}, 2 \mathrm{H})$, 1.53-1.45 (m, 2H), $1.02(\mathrm{t}, J=7.2 \mathrm{~Hz}, 3 \mathrm{H}), 0.08(\mathrm{~s}, 6 \mathrm{H})$. ${ }^{13} \mathrm{C} \mathrm{NMR}\left(101 \mathrm{MHz}, \mathrm{CDCl}_{3}\right): \delta 169.61,168.48,148.19$, $147.22,144.38,144.01,142.19,141.01,137.00,135.52$, $133.26,132.55,132.26,130.10,129.23,127.47,126.15$, 52.36, 51.84, 32.04, 29.47, 22.26, 13.97, - 2.47. LC-MS, $\mathrm{m} / \mathrm{z}: 473.1[\mathrm{M}+\mathrm{H}]^{+}$

\section{Synthesis of Dimethoxycarbonyl-Substituted Benzonaphthosilole Derivative}

Benzonaphthosilole derivative with propyl, phenyl, and dimethoxycarbonyl substituents was synthesized from 4-octyne, phenylacetylene, and 1,4-dibromobenzene, and the synthetic route is shown in Scheme 3.

Preparation Procedure for 1,4-Dibromo-2,5-Diiodobenzene

The preparation of 1,4-dibromo-2,5-diiodobenzene does not need nitrogen protection. First, $60 \mathrm{~mL}$ of $\mathrm{H}_{2} \mathrm{SO}_{4}$ $(98 \%)$ was added dropwise to periodic acid $\left(\mathrm{H}_{5} \mathrm{IO}_{6}\right.$, $2.66 \mathrm{~g}, 11.7 \mathrm{mmol}$ ) at $0{ }^{\circ} \mathrm{C}$. Potassium iodide (KI, $5.82 \mathrm{~g}$, $35.1 \mathrm{mmol}$ ) was added four times at intervals of $10 \mathrm{~min}$, and $15 \mathrm{~min}$ later, 1,4-dibromobenzene (5.52 g, $23.4 \mathrm{mmol}$ ) and $\mathrm{H}_{2} \mathrm{SO}_{4}(98 \%, 24 \mathrm{~mL})$ were added slowly. The mixture was stirred at $0{ }^{\circ} \mathrm{C}$ for $12 \mathrm{~h}$ and warmed overnight to room temperature. The obtained mixture was poured in ice water and filtered, and the cake was dissolved in chloroform and washed with $\mathrm{NaOH}$ solution (5\%). The organic phase solution was removed under reduced pressure, and the residue was recrystallized with chloroform and THF $(v: v=2: 1)$ to give 1,4-dibromo-2,5-diiodobenzene.

Spectroscopic data

1,4-dibromo-2,5-diiodobenzene [25]: ${ }^{1} \mathrm{H}$ NMR (400 MHz, $\left.\mathrm{CDCl}_{3}\right): \delta 8.04(\mathrm{~s}, 2 \mathrm{H})$. 


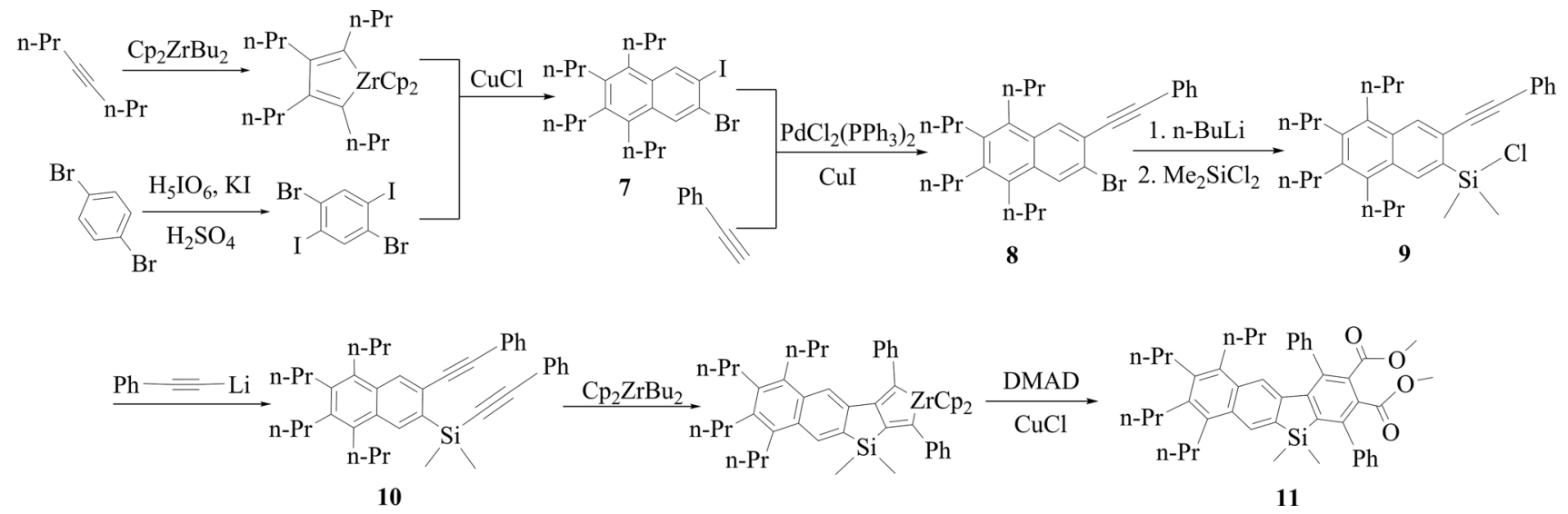

Scheme 3 Synthesis of dimethoxycarbonyl-substituted benzonaphthosilole derivative

\section{Preparation Procedure for Benzonaphthosilole Derivative (11)}

First, $15.6 \mathrm{~mL}$ of $\mathrm{n}-\mathrm{BuLi}(2.5 \mathrm{~mol} / \mathrm{L}, 39 \mathrm{mmol})$ was added dropwise to the mixture of $\mathrm{Cp}_{2} \mathrm{ZrCl}_{2}(5.9 \mathrm{~g}, 19.5 \mathrm{mmol})$ and THF $(100 \mathrm{~mL})$ at $-78{ }^{\circ} \mathrm{C}$, and the resulting mixture was stirred for $1 \mathrm{~h}$. Then, 4-octyne $(3.31 \mathrm{~g}, 30 \mathrm{mmol})$ was added, and the mixture was stirred at room temperature for $2 \mathrm{~h}$ and cooled to $0{ }^{\circ} \mathrm{C}$. Cuprous chloride $(4.45 \mathrm{~g}, 45 \mathrm{mmol})$ was added, and the mixture was stirred at room temperature for $10 \mathrm{~min}$. Subsequently, 1,3-dimethyl-tetrahydropyrimidin2(1H)-one (DMPU, $7.3 \mathrm{~mL}, 60 \mathrm{mmol}$ ) and 1,4-dibromo2,5-diiodobenzene (14.63 g, $30 \mathrm{mmol}$ ) were added, and the obtained mixture was heated to $50{ }^{\circ} \mathrm{C}$ for $2 \mathrm{~h}$. The reaction was quenched with dilute hydrochloric acid and extracted with ethyl acetate. The organic phase solvent was removed under a reduced pressure and the residue was purified by flash column chromatography on silica gel with n-hexane to give 6-bromo-7-iodo-1,2,3,4-tetrapropylnaphthalene (7).

The synthesis procedures of 6-bromo-7-phenylethynyl1,2,3,4-tetrapropylnaphthalene (8), 6-chlorodimethylsily7-phenylethynyl-1,2,3,4-tetrapropylnaphthalene (9), and 6-(phenylethynyl)dimethylsily-7-phenylethynyl-1,2,3,4tetrapropylnaphthalene (10) are the same as those of 2, 3, and 5.

In a dropwise manner, $2.13 \mathrm{~mL}$ of $\mathrm{n}-\mathrm{BuLi}(1.6 \mathrm{~mol} / \mathrm{L}$, $3.4 \mathrm{mmol})$ was added to the mixture of $\mathrm{Cp}_{2} \mathrm{ZrCl}_{2}(0.5 \mathrm{~g}$, $1.7 \mathrm{mmol})$ and THF $(5 \mathrm{~mL})$ at $-78{ }^{\circ} \mathrm{C}$, and the mixture was stirred for $1 \mathrm{~h}$. Then, $\mathbf{1 0}(0.56 \mathrm{~g}, 1 \mathrm{mmol})$ was added, and the obtained mixture was heated to $70{ }^{\circ} \mathrm{C}$ for $1 \mathrm{~h}$. The mixture was cooled to $0{ }^{\circ} \mathrm{C}$, and $\mathrm{CuCl}(0.38 \mathrm{~g}, 3 \mathrm{mmol})$ was added, and then, the mixture was warmed to room temperature for 10 min. Subsequently, DMAD (0.57 g, $4 \mathrm{mmol})$ was added, and the mixture was heated to $65^{\circ} \mathrm{C}$ for $2 \mathrm{~h}$. The reaction was quenched with saturated ammonium chloride solution and extracted with ethyl acetate. The organic phase solvent was removed under a reduced pressure, and the residue was purified by flash column chromatography on silica gel with n-hexane and ethyl acetate $(v / v=5: 1)$ to give dimethyl 5,5-dimethyl-7,10-diphenyl-1,2,3,4-tetrapropylbenzo[b] naphtho[2,3- $d]$ silole-8,9-dicarboxylatepropyl (11).

Spectroscopic data

6-bromo-7-iodo-1,2,3,4-tetrapropylnaphthalene (7): ${ }^{1} \mathrm{H}$ NMR (400 MHz, $\left.\mathrm{CDCl}_{3}\right): \delta 8.50(\mathrm{~s}, 1 \mathrm{H}), 8.24(\mathrm{~s}, 1 \mathrm{H}), 2.93$ (ddd, $J=11.3,5.3,3.0 \mathrm{~Hz}, 4 \mathrm{H}), 2.76-2.69$ (m, 4H), 1.68$1.55(\mathrm{~m}, 8 \mathrm{H}), 1.15-1.09(\mathrm{~m}, 12 \mathrm{H})$

6-bromo-7-phenylethynyl-1,2,3,4-tetrapropylnaphthalene (8): ${ }^{1} \mathrm{H} \mathrm{NMR}\left(400 \mathrm{MHz}, \mathrm{CDCl}_{3}\right): \delta 8.19(\mathrm{~d}, J=6.8 \mathrm{~Hz}, 1 \mathrm{H})$, 7.67-7.63 (m, 1H), 3.01-2.90 (m, 2H), 2.71 (ddd, $J=11.7$, 4.9, $3.1 \mathrm{~Hz}, 2 \mathrm{H}), 1.71-1.61(\mathrm{~m}, 2 \mathrm{H}), 1.61-1.54(\mathrm{~m}, 2 \mathrm{H})$, $1.15-1.07(\mathrm{~m}, 6 \mathrm{H})$

6-(phenylethynyl)dimethylsily-7-phenylethynyl-1,2,3,4tetrapropylnaphthalene (10): $\left.{ }^{1} \mathrm{H} \mathrm{NMR} \mathrm{(400} \mathrm{MHz}, \mathrm{CDCl}_{3}\right)$ : $\delta 8.64(\mathrm{~s}, 1 \mathrm{H}), 8.22(\mathrm{~s}, 1 \mathrm{H}), 7.66-7.63(\mathrm{~m}, 2 \mathrm{H}), 7.55-7.52$ $(\mathrm{m}, 2 \mathrm{H}), 7.37(\mathrm{q}, J=2.5 \mathrm{~Hz}, 3 \mathrm{H}), 7.33-7.30(\mathrm{~m}, 3 \mathrm{H}), 3.04$ (dd, $J=7.3,4.4 \mathrm{~Hz}, 4 \mathrm{H}), 2.75(\mathrm{dd}, J=7.9,4.5 \mathrm{~Hz}, 4 \mathrm{H})$, 1.74-1.69 (m, 4H), 1.59 (dt, $J=6.7,2.1 \mathrm{~Hz}, 4 \mathrm{H}), 1.14$ (ddd, $J=13.0,7.4,2.8 \mathrm{~Hz}, 12 \mathrm{H}), 0.73(\mathrm{~s}, 6 \mathrm{H})$

Dimethyl 5,5-dimethyl-7,10-diphenyl-1,2,3,4tetrapropylbenzo[b]naphtho[2,3-d]silole-8,9-dicarboxylatepropyl (11): ${ }^{1} \mathrm{H} \mathrm{NMR}\left(400 \mathrm{MHz}, \mathrm{CDCl}_{3}\right): \delta 8.10(\mathrm{~s}, 1 \mathrm{H})$, $7.66(\mathrm{~s}, 1 \mathrm{H}), 7.50(\mathrm{dt}, J=4.9,2.5 \mathrm{~Hz}, 3 \mathrm{H}), 7.46-7.40(\mathrm{~m}$, $5 \mathrm{H}), 7.34(\mathrm{dd}, J=7.3,2.1 \mathrm{~Hz}, 2 \mathrm{H}), 3.47$ (s, 3H), 3.43 (s, 3H), $2.96(\mathrm{dd}, J=9.4,6.6 \mathrm{~Hz}, 2 \mathrm{H}), 2.68-2.62(\mathrm{~m}, 2 \mathrm{H}), 2.61-2.55$ $(\mathrm{m}, 2 \mathrm{H}), 2.23(\mathrm{t}, J=8.0 \mathrm{~Hz}, 2 \mathrm{H}), 1.62(\mathrm{q}, J=7.8 \mathrm{~Hz}, 2 \mathrm{H})$, 1.48 (ddt, $J=16.3,12.0,7.9 \mathrm{~Hz}, 6 \mathrm{H}), 1.16(\mathrm{q}, J=7.6 \mathrm{~Hz}$, 2H), 1.09-1.00 (m, 10H), $0.11(\mathrm{~s}, 6 \mathrm{H}) .{ }^{13} \mathrm{C} \mathrm{NMR}(101 \mathrm{MHz}$, $\left.\mathrm{CDCl}_{3}\right): \delta 168.30,147.81,146.10,141.45,141.07,139.60$, 
$138.05,137.58,136.73,135.62,135.10,133.83,131.72$, $130.17,129.32,128.01,127.68,51.97,32.57,24.58,14.77$, -1.58 . LC-MS, $m / z: 697.2[\mathrm{M}+\mathrm{H}]^{+}$

\section{Results and Discussion}

In this study, new zirconium-mediated cycloaddition strategies for synthesizing several novel dibenzosilole and benzonaphthosilole derivatives are developed. Using these methods, EWG, alkyl, and phenyl groups can be selectively introduced onto the aromatic rings of these new derivatives.

The Sonogashira coupling of $\mathbf{1}$ and 1-bromo-2-iodobenzene in the presence of $\mathrm{Pd}\left(\mathrm{PPh}_{3}\right)_{2} \mathrm{Cl}_{2}$ and $\mathrm{CuI}$ produced high yields of 2 and $\mathbf{8}$. However, when $\mathrm{Pd}\left(\mathrm{Ph}_{3}\right)_{4}$ and $\mathrm{CuI}$ were used as catalysts, the reaction was sluggish and did not accelerate with an increase in temperature. This suggests that $\mathrm{Pd}\left(\mathrm{PPh}_{3}\right)_{2} \mathrm{Cl}_{2}$ is the suitable catalyst for this reaction. Since iodine is more reactive than bromine, the Sonogashira coupling occurred selectively at the iodine position, and the introduction of $\mathrm{R}^{1}$ and $\mathrm{R}^{2}$ groups could be effectively controlled.

Side reactions occurred when $\mathrm{Me}_{2} \mathrm{SiCl}_{2}$ was added dropwise during the synthesis of $\mathbf{3}$ and $\mathbf{9}$. These reactions reduced when $\mathrm{Me}_{2} \mathrm{SiCl}_{2}$ was added in one portion. This indicates that insufficient amount of $\mathrm{Me}_{2} \mathrm{SiCl}_{2}$ would react with double its amount of lithiated molecules of $\mathbf{2}$ and $\mathbf{8}$ to give by-products, and adding $\mathrm{Me}_{2} \mathrm{SiCl}_{2}$ in one portion reduced the by-products. To prevent overheating in the process of adding $\mathrm{Me}_{2} \mathrm{SiCl}_{2}$ in one portion, $\mathrm{Me}_{2} \mathrm{SiCl}_{2}$ and the reaction mixture were first cooled to $-78{ }^{\circ} \mathrm{C}$. Given that $\mathrm{Si}-\mathrm{Cl}$ bonds in $\mathbf{3}$ and $\mathbf{9}$ can hydrolyze easily, n-hexane was used as the quencher. In addition, the corresponding quenching, filtration, and concentration operations were carried out under nitrogen atmosphere.

The reaction mechanism of zirconium-mediated cycloaddition of silicon-bridged diynes is shown in Scheme 4. It has been reported that zirconacyclopentadienes can react with electron-withdrawing alkynes to give benzene derivatives $[26,27]$. It was speculated that silolozirconacyclopentadiene intermediates were formed from the reaction of silicon-bridged diynes with $\mathrm{Cp}_{2} \mathrm{ZrBu}_{2}$. The treatment of silolozirconacyclopentadienes with $\mathrm{CuCl}$ generated coppersubstituted butadiene intermediates, which was followed by an insertion reaction with EWG-substituted alkynes at the $\mathrm{C}-\mathrm{Cu}$ bond, and copper-substituted 1,3,5-hexatriene intermediates were produced. Then a six-membered ring molecule was formed via Michael addition reaction. Afterward, $\mathrm{Cu}(\mathrm{I})$ at $\mathrm{C}-\mathrm{Cu}$ bond was reduced to $\mathrm{Cu}(0)$, at which point EWG-substituted silole derivatives were formed. Through this reaction, $\mathrm{Cu}(\mathrm{I})$ was converted to $\mathrm{Cu}(0)$, which suggests that $\mathrm{CuCl}$ was not a catalyst but a reactant. Moreover, a copper mirror was observed on the inner wall of the bottle after this reaction.

As for the formation of silolozirconacyclopentadienes of $\mathbf{5}$, the conversion rate of silicon-bridged diynes was greatly affected by the temperature. As detected by TLC, the conversion rate was low after $3 \mathrm{~h}$ of reaction at room temperature. Surprisingly, $30-40 \mathrm{~min}$ of stirring at $50{ }^{\circ} \mathrm{C}$ resulted in a high conversion rate. The results showed that $50{ }^{\circ} \mathrm{C}$ was the optimum temperature for the silolozirconacyclopentadienes formation. In addition, a longer time was needed for this reaction when there was an alkyl group on the siliconbridged diynes.

To optimize the reaction temperature of the EWG-substituted alkynes cycloaddition, the reaction of $6 \mathbf{a}$ was investigated, and different temperatures were tried $(25,35,50$, 60 , and $70{ }^{\circ} \mathrm{C}$ ). It took these reactions $6 \mathrm{~h}$ at $25^{\circ} \mathrm{C}, 1 \mathrm{~h}$ at
Scheme 4 Reaction mechanism of zirconium-mediated cycloaddition of silicon-bridged diynes
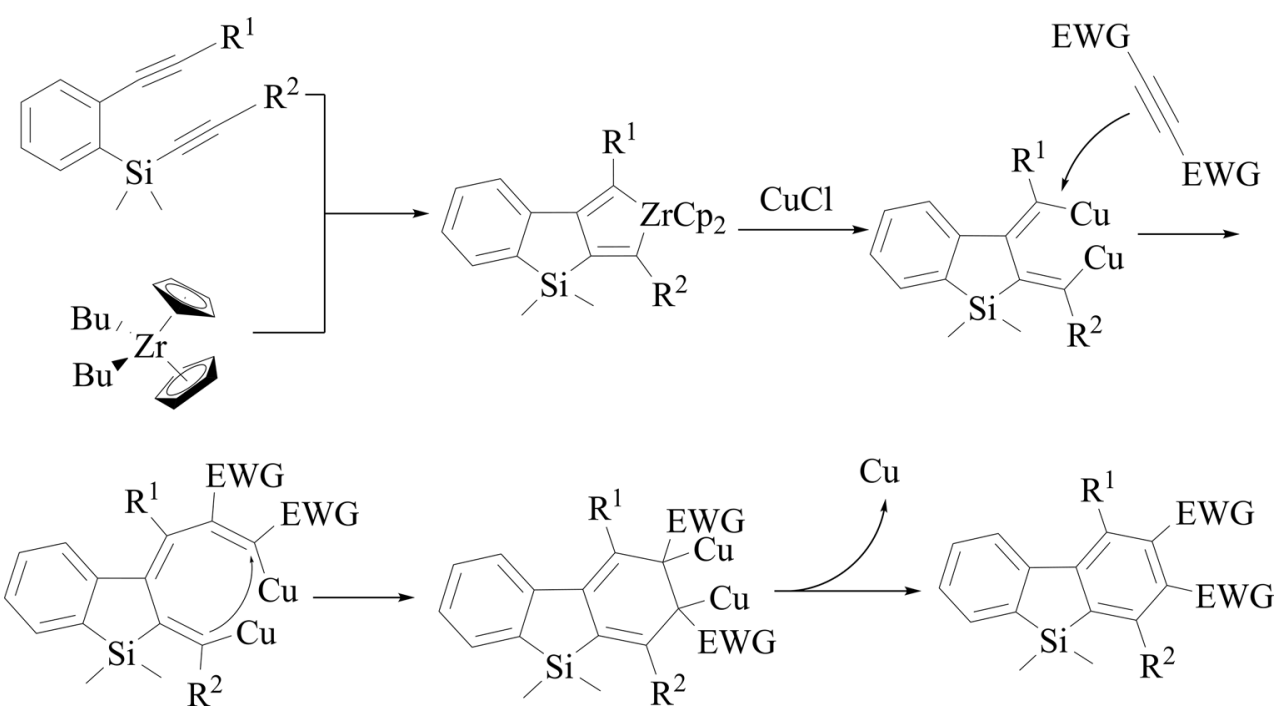
Table 1 Synthesis of novel dibenzosilole derivatives

\begin{tabular}{llllll}
\hline Entry & Name & $\mathrm{R}^{1}$ & $\mathrm{R}^{2}$ & $\mathrm{R}^{3}$ & ${\text { Yield }(\%)^{\mathrm{a}}}^{\mathrm{a}}$ \\
\hline 1 & 2a & Phenyl & - & - & 83 \\
2 & 2b & Pentyl & - & - & 87 \\
3 & $\mathbf{5 a}$ & Phenyl & Phenyl & - & 79 \\
4 & $\mathbf{5 b}$ & Phenyl & Pentyl & - & 49 \\
5 & $\mathbf{5 c}$ & Pentyl & Phenyl & - & 63 \\
6 & 6a & Phenyl & Phenyl & Methoxycarbonyl & 79 \\
7 & 6b & Phenyl & Phenyl & Ethoxycarbonyl & 65 \\
8 & 6c & Phenyl & Pentyl & Methoxycarbonyl & 69 \\
9 & 6d & Pentyl & Phenyl & Methoxycarbonyl & 64 \\
\hline
\end{tabular}

${ }^{a}$ Isolated yields

$35^{\circ} \mathrm{C}$, and $15 \mathrm{~min}$ at $50{ }^{\circ} \mathrm{C}$ to prepare $\mathbf{6 a}$, and by-products were detected by TLC when the temperature was higher than $60{ }^{\circ} \mathrm{C}$. Based on these, $50{ }^{\circ} \mathrm{C}$ was chosen as the optimum temperature for the cycloaddition reaction of EWG-substituted alkynes.

The yields of the substances obtained during the preparation of dibenzosilole derivatives are listed in Table 1. Phenyl-, pentyl-, and alkoxycarbonyl-substituted dibenzosilole derivatives were obtained in yields of $64-79 \%$ by zirconium-mediated cycloaddition (entries 6-9). In contrast to iridium(I)-catalyzed cycloaddition reaction [16], novel dibenzosilole derivatives were efficiently prepared (entries 7-9), in addition to the high yield of dimethoxycarbonylsubstituted derivative obtained (entry 6). This indicates that zirconium-mediated cycloaddition has good adaptability to silicon-bridged diynes bearing different substituents.

During the synthesis of 11, TLC detected that the silolozirconacyclopentadiene intermediate formation was sluggish at $50{ }^{\circ} \mathrm{C}$. Considering the steric effect of the naphthyl group, $55,60,65$, and $70{ }^{\circ} \mathrm{C}$ were attempted. It took $1 \mathrm{~h}$ for the reaction to convert silicon-bridged diynes into intermediates even at $70{ }^{\circ} \mathrm{C}$, and the conversion was slower for lower temperatures. Therefore, $70^{\circ} \mathrm{C}$ was selected as the optimum temperature for the formation of the silolozirconacyclopentadiene intermediate of $\mathbf{1 0}$.

For the cycloaddition of dimethyl but-2-ynedioate to obtain $11,50,55,60,65$, and $70{ }^{\circ} \mathrm{C}$ were tried. The reactions were slow when the temperatures were below $65^{\circ} \mathrm{C}$, and at $70{ }^{\circ} \mathrm{C}$, the separation of $\mathbf{1 1}$ was greatly affected by the large amount of by-products. In contrast, $2 \mathrm{~h}$ of reaction
Scheme 5 Synthesis of novel benzonaphthosilole derivative (all the yields were isolated yields)

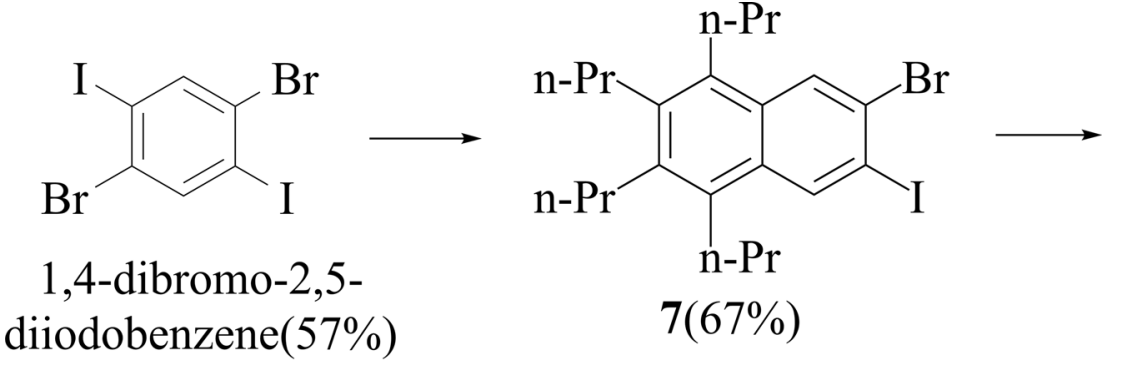<smiles>CCCc1c(CCC)c([Al]CC)c2cc([Si](C)(C)C#Cc3ccccc3)c(C#Cc3ccccc3)cc2c1[15CH]</smiles>

10(56\%)

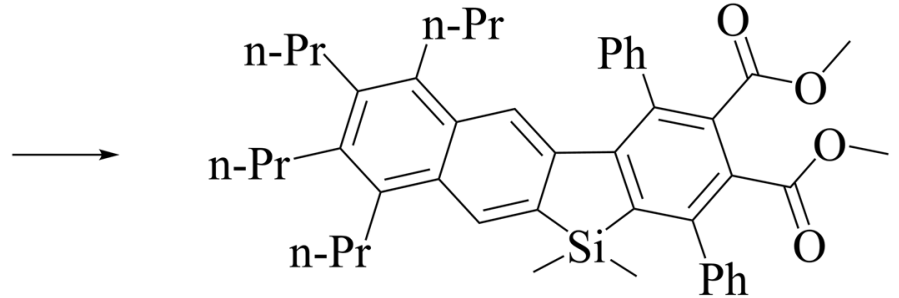

11(49\%) 
at $65{ }^{\circ} \mathrm{C}$ moderately yielded 11 ; hence, it was chosen as the optimum temperature for the cycloaddition to prepare $\mathbf{1 1}$.

The yields obtained during the preparation of benzonaphthosilole derivative are listed in Scheme 5. As noted above, there are few reports on the synthesis of benzonaphthosilole derivatives. Our report on the synthesis of $\mathbf{1 1}$ is unique, because to date, it is the only synthesized benzonaphthosilole derivative with substituents on the aromatic rings. The structure and synthesis strategy of $\mathbf{1 1}$ are rather different from those of the previous literature [17-19]. In contrast to the rhodium-catalyzed reaction, the synthesis strategy we designed uses readily available alkynes as the starting materials instead of dimethyl[2-(naphthalen-2-yl) phenyl]silane, which is difficult to prepare. Moreover, propyl, phenyl and dimethoxycarbonyl groups can be selectively introduced onto the aromatic rings of $\mathbf{1 1}$ by combining zirconium-mediated coupling reaction, Sonogashira coupling reaction, and the novel zirconium-mediated cycloaddition reported in this paper. The result of preparing $\mathbf{1 1}$ shows that zirconium-mediated cycloaddition has excellent adaptability to silicon-bridged diynes bearing a larger group as naphthyl. This indicates that zirconium-mediated cycloaddition reactions of silicon-bridged diynes can be used to synthesize various silole derivatives.

\section{Conclusions}

In summary, a new method of synthesizing alkoxycarbonylsubstituted dibenzosilole derivatives was developed, and the preparation of $\mathbf{5 c}, \mathbf{6 b}, \mathbf{6 c}$, and $\mathbf{6 d}$ was reported for the first time. High yields of dibenzosilole derivatives were obtained, which were much higher than that of iridium(I)-catalyzed cycloaddition. In addition, we successfully designed a strategy based on zirconium-mediated cycloaddition reaction for synthesizing a moderate yield of benzonaphthosilole derivative bearing several substituents, which suggests that this reaction is suitable to silicon-bridged diynes bearing different groups. By synthesizing compound 11, we successfully accomplished the selective and multiple derivatization of benzonaphthosilole. Using the synthesis strategies we reported, alkoxycarbonyl, phenyl, and alkyl-substituted dibenzosilole and benzonaphthosilole derivatives were efficiently synthesized, where the alkoxycarbonyl, phenyl, and alkyl groups were selectively introduced onto the aromatic rings. All raw materials of the cycloaddition reactions are available or easily prepared. In addition, alkoxycarbonyl groups have potential for further derivatization, which is of great significance for expanding the range of applications of silole derivatives. These novel zirconium-mediated cycloaddition synthesis strategies can provide a wider variety of silole derivatives.
Acknowledgements This study was supported by the National Natural Science Foundation of China (No. 21102099).

Open Access This article is distributed under the terms of the Creative Commons Attribution 4.0 International License (http://creativeco mmons.org/licenses/by/4.0/), which permits unrestricted use, distribution, and reproduction in any medium, provided you give appropriate credit to the original author(s) and the source, provide a link to the Creative Commons license, and indicate if changes were made.

\section{References}

1. Hong YN, Lam JWY, Tang BZ (2011) Aggregation-induced emission. Chem Soc Rev 40:5361-5388

2. Tamao K, Uchida M, Izumizawa T et al (1996) Silole derivatives as efficient electron transporting materials. J Am Chem Soc 118:11974-11975

3. Quan CY, Nie H, Hu RR et al (2015) A silole-based efficient electroluminescent material with good electron-transporting potential. Chin J Chem 33:842-846

4. Anthony JE, Facchetti A, Heeney M et al (2010) N-type organic semiconductors in organic electronics. Adv Mater 22:3876-3892

5. Erlik O, Unlu NA, Hizalan G et al (2015) Silafluorene-based polymers for electrochromic and polymer solar cell applications. J Polym Sci Pol Chem 53:1541-1547

6. Duan CH, Cai WZ, Huang F et al (2010) Novel silafluorene-based conjugated polymers with pendant acceptor groups for high performance solar cells. Macromolecules 43:5262-5268

7. Yuan MJ, Yang PY, Durban MM et al (2012) Low bandgap polymers based on silafluorene containing multifused heptacylic arenes for photovoltaic applications. Macromolecules 45:5934-5940

8. Wang E, Li C, Zhuang WL et al (2008) High-efficiency red and green light-emitting polymers based on a novel wide bandgap poly(2,7-silafluorene). J Mater Chem 18:797-801

9. Yang J, Aschemeyer S, Martinez HP et al (2010) Hollow silica nanospheres containing a silafluorene-fluorene conjugated polymer for aqueous TNT and RDX detection. Chem Commun 46:6804-6806

10. Ouyang KB, Liang Y, Xi ZF (2012) Construction of benzosiloles, six- and eight-membered silacyclic skeletons, via a Pd-catalyzed intramolecular Mizoroki-Heck Reaction of vinylsilanes. Org Lett 14(17):4572-4575

11. Li LC, Xiang JF, Xu CH (2007) Synthesis of novel ladder bissilicon-bridged p-terphenyls. Org Lett 9(23):4877-4879

12. Murai M, Matsumoto K, Okada R et al (2014) Rhodium-catalyzed dehydrogenative germylation of $\mathrm{C}-\mathrm{H}$ bonds: new entry to unsymmetrically functionalized 9-germafluorenes. Org Lett 16:6492-6495

13. Xu L, Zhang S, Li PF (2015) Synthesis of silafluorenes and silaindenes via silyl radicals from arylhydrosilanes: intramolecular cyclization and intermolecular annulations with alkynes. Org Chem Front 2:459-463

14. Murata M, Takizawa M, Sasaki H et al (2016) Synthesis of dibenzosiloles via Platinum-catalyzed intramolecular dehydrogenative cyclization of 2-(Dialkylsilyl)biaryls. Chem Lett 45:857-859

15. Hudrlik PF, Dai DH, Hudrlik AM (2006) Reactions of dilithiobutadienes with monochlorosilanes: observation of facile loss of organic groups from silicon. J Organomet Chem 691:1257-1264

16. Matsuda T, Kadowaki S, Goya T et al (2007) Synthesis of silafluorenes by Iridium-catalyzed $[2+2+2]$ cycloaddition of siliconbridged diynes with alkynes. Org Lett 9(1):133-136 
17. Murai M, Okada R, Asako S et al (2017) Rhodium-catalyzed silylative and germylative cyclization with dehydrogenation leading to 9-sila- and 9-germafluorenes: a combined experimental and computational mechanistic study. Chem Eur J 23:10861-10870

18. Ureshino T, Yoshida T, Kuninobu Y et al (2010) Rhodiumcatalyzed synthesis of silafluorene derivatives via cleavage of silicon-hydrogen and carbon-hydrogen bonds. J Am Chem Soc 132:14324-14326

19. Murai M, Okada R, Nishiyama A et al (2016) Synthesis and properties of sila[n]helicenes via dehydrogenative silylation of $\mathrm{C}-\mathrm{H}$ bonds under Rhodium catalysis. Org Lett 18:4380-4383

20. Seri T, Qu HM, Zhou LS et al (2008) Substituent effects in the preparation of naphthacenes by the coupling reaction of diynederived zirconacyclopentadienes with tetraiodobenzene. Chem Asian J 3:388-392

21. Li S, Qu HM, Zhou LS et al (2009) Zirconium-mediated selective synthesis of 1,2,4,5-tetrasubstituted benzenes from two silyl-substituted alkynes and one internal alkyne. Org Lett 11(15):3318-3321

22. Wang H, Li JQ, Zhou LS et al (2015) Palladium-catalyzed synthesis of 1,2,3,4-tetraalkyl-1,4-diarylbutadienes by cross-coupling of zirconacyclopentadienes with aryl iodides. Chin Chem Lett 26:1303-1306

23. Arndt S, Hansmann MM, Motloch P et al (2017) Intramolecular anti-phosphinoauration of alkynes: an FLP-motivated approach to stable aerated phosphindolium complexes. Chem Eur J 23:2542-2547

24. Just G, Singh R (1987) The synthesis of 11-13-membered diacetylenic and 18-membered tetraacetylenic ring systems. Tetrahedron Lett 28(48):5981-5984

25. Duhovic S, Dinca M (2015) Synthesis and electrical properties of covalent organic frameworks with heavy chalcogens. Chem Mater 27:5487-5490

26. Takahashi T, Xi ZF, Yamazaki A et al (1998) Cycloaddition reaction of zirconacyclopentadienes to alkynes: highly selective formation of benzene derivatives from three different alkynes. J Am Chem Soc 120:1672-1680

27. Li JQ, Zhang JQ, Qu HM et al (2016) Zirconium-mediated selective synthesis of 1,4-dialkyl(aryl)-hexa-substituted benzenes from two silyl-substituted alkynes and one internal alkyne. Chem Res Chin Univ 32(3):366-372 